\title{
VICE PRESIDENTIAL CANDIDATES IN THE AMERICAN PRESIDENTIAL ELECTIONS: STRATEGIES FOR SELECTION AND EFFECTS
}

\author{
Marco Morini, \\ Padova University, Italy.
}

\begin{abstract}
American vice presidential candidates are chosen for several reasons. Some of these rationales are easy to be recognized, while others belong to the cockles of the heart of the presidential candidates. Social scientists and journalists agree about the factors that are more essential: the vice presidential (VP) nominee's capacity of balancing the ideological and personal characteristics of the presidential candidate and the "native son" effect, namely the guarantee that the VP nominee would carry his/her own state. These strategies are often combined and they work at different electoral levels: the first one has usually a national or macro-regional significance while the second is crucial in the battleground states. This research is divided into two sections: the first one investigates the "balancing the ticket" strategy, offering an overview of about one century of presidential races. The second aims to verify the VP nominee's effect in his/her home state. The results will confirm that there have been several running mates who have been selected in order to "balance the ticket" but also that the vice president nominee's effect in the home states has been quite poor.
\end{abstract}

Keywords: American Politics; American Political History; American Presidential Campaigns; Political Strategies and Party Politics. 


\section{Introduction}

An accepted wisdom is that vice presidential candidates are of minor importance to most voters. Perhaps as a result there have not been much research aimed at the reasons and the effect of vice presidential nominee selection (Adkinson 1982, 331; Wattenberg 1995) and most of them tried to measure a "national effect" (Wattenberg and Grofman 1993, 175; Grofman and Kline 2010). Particularly, Grofman and Kline study examined voters' specific preferences for both President and Vice President and found that about $11 \%$ of the population on average has "conflicted" preferences - where a voter prefers the presidential candidate of one party but also likes the vice presidential nominee of the other party. Using this data, they estimate the degree to which a vice presidential candidate alone might determine the electoral result. The two scholars note that these patterns of "conflicted" voting behaviour have decreased over time: only 6.9 per cent and 6.8 per cent of the electorate had conflicted preferences in 2004 and 2008, likely the outcome of "increasing partisan polarization." Grofman and Kline found out that the direct effect of a vice presidential candidate is generally less than 1 per cent in terms of getting voters to cross party lines:

Only in 1972 was more than 1 per cent of the final vote affected by conflicted vice presidential and presidential preferences; on average, over the 1968-2008 period, the net impact of conflicted presidential and vice presidential choices is only slightly less than $0.6 \%$ of the votes shifted (p. 1).

Grofman and Kline also pointed out that there were two relevant caveats to their findings:

Data may understate the impact of vice presidential selection on choice because voters modify their views of the president based on vice presidential selection, and thus the data we report may be 'contaminated' by unmeasured effects of vice presidential choice. Second, mobilizing effects of vice presidential choice vis-à-vis turnout or campaign contributions or campaign activism are not reflected in our measures. For example, the selection of Sarah Palin was widely credited in the media as having motivated a Republican base that did not find McCain that attractive a candidate" (Grofman and Kline 2010, 1).

And, in order to better approach this field of study, we also should not forget that popular culture sees voters taking the president and the vice president as a "package deal." 
It is interesting to note that Palin's choice revived academic interest around the figure of the Vice Presidential nominees. Ulbig (2010) focused her research on what extent do vice presidential candidates affect individual-level vote choice for president. She found out that when vice presidential candidates draw media interest, feelings about them become much more relevant to voters. Investigating Palin's candidacy, who drew high level of media attention, Ulbig discovered that feelings about her exerted a stronger impact on vote choice, especially among Independent voters.

Other research explored the so-called "home-state effect", that is well-known for Presidential candidates and kind of controversial for VP nominees: Devine and Kopko (2011) argue that selecting a vice presidential candidate from a small state is not sufficient to produce a significant vice presidential home state advantage. The same authors, a few years later (2013), found out that vice presidential home state advantages are statistically negligible and conditioned on the interactive effect of political experience and state population. Furthermore, their results indicate that the mobilization of new voters primarily accounts for presidential home state advantage, while vice presidential home state advantage is mainly due to the conversion of existing voters.

Our research goes on a different direction: first, we go through the last 24 presidential elections and we try to understand which rationales brought presidential candidates to choose their running mates. Reasoning on a qualitative level, we aim to show the different strategies employed by the parties and the candidates in order to make the tickets more appealing to the populations and so to maximize votes.

In the second section, we measure the actual vice presidential nominee effect, at least in his/her home state. By monitoring the difference between the performance of the ticket at the national level with the one in the VP home state and comparing this margin with the one obtained in the previous and in the subsequent presidential election, we are able to estimate the VP effect at state-level.

\section{The First Strategy: Balancing the Ticket}

Many observers think that John F. Kennedy's selection of Lyndon Johnson as vice presidential nominee helped him winning the South in 1960. However, citizens' electoral behaviour is mainly driven by the name at the top of the ticket and there are probably not many voters who are attracted from who a candidate chooses as his VP. Nevertheless, the selection of a running mate can give voters a better viewpoint into the kind of person, and politician, a presidential candidate really is.

Since the vice presidential selection process captures a lot of media attention, 
presidential scholars agree that a candidate selecting a running mate should try to avoid controversies. Generally speaking, one of the main rules for picking a VP nominee follows the saying 'first, do no harm'. And yet, this is often infringed. That is because finding a recognized figure with no contraindications is hard, since all high profile politicians have negative traits linked to their image.

The presidential candidate and his campaign staff have difficult choices to make. First of all, they have to decide whether to run with a VP candidate who integrates the top of ticket, helping him to win battleground states, or instead select someone who strengthens the nominee's image. In 2008, Senator John McCain experienced how the early assumptions can change over time, when his attempt to galvanize conservatives and rural sympathizers by choosing Sarah Palin did not work out as expected. Another example of how the original purposes can derail are those of Missouri Senator Thomas Eagleton, selected but then rapidly dismissed by George McGovern in 1972, after evidence emerged about his mental health problems, and of Dan Quayle, whom George H.W. Bush chose in 1988 hoping that he would help the campaign in gaining in popularity among young voters. Instead, Quayle became a sort of "a national joke" (Goldstein 2007).

Nominees from the moderate part of the Republican Party, such as Gerald Ford, George H.W. Bush, Bob Dole and John McCain have felt obliged to select vice presidential candidates who are favourite by the party's right wing (Quayle, Jack Kemp and Sarah Palin above all). On the other hand, Ronald Reagan thought he had to demonstrate that he was open to more moderate views and decided to select George H. W. Bush, a centrist experienced Texas politician. Among Democrats, Walter Mondale and Lloyd Bentsen also appeared to be sort of "balancing acts" for Jimmy Carter and Michael Dukakis respectively. Finally, Bill Clinton decided to strengthen his image as "New Democrat", picking another emerging Southern politician, Al Gore.

In recent years, many political scientists argued that in 2008 Joe Biden has been selected because he is white, mature and experienced, in order to balance the ticket with the young, black and less experienced Barack Obama. With the same logic, John Edwards would have been picked to gain votes in the Southern states and in order to balance the "elitist and New Englander" John Kerry's image. And in 2012, Paul Ryan has probably been selected for his conservative policy standings, his youthful energy and powerful speech making. Indeed, the previous five Republican vice presidential candidates were all conservative and they were usually chosen for balancing out some possible weakness at the top of the ticket (Gruhl et al. 2012, 228).

Dick Cheney was expected to give dignity and international politics experience 
to George W. Bush. Dan Quayle and Sarah Palin were supposed to bring young votes to George H. W. Bush and John McCain (Mitt Romney has almost never been criticized for being "too old," maybe because he looked much younger than his 65 years). Bob Dole's choice of Jack Kemp is probably more similar to Romney's selection of Paul Ryan. Kemp, who by the way was one of Ryan's political mentors, was conservative on fiscal policy, like Ryan. But he was moderate on social policy, which Ryan is not. In 1996, Bill Clinton performed very well in rural zones, something unusual for "modern" Democrats, so Dole probably thought that Jack Kemp could move forward Republicans' reputation in the urban areas (Gruhl et al. 2012, 229).

That is for what concerns recent elections. But the whole history of the American presidential elections is full of stories that show in different manners which reasons stay behind VP nominee selection. Most of these insights are anecdotal, but some of the most distant campaigns enforce the idea that "balancing the ticket" is one of strategies that are most employed by the presidential candidates.

One of the best known VP nominee selection happened in 1984. As soon as Walter Mondale secured the Democratic nomination, the idea of choosing a woman as his vice presidential candidate got significant public opinion attention. The National Organization for Women and the National Women's Political Caucus supported the idea, as did several high profile Democratic figures such as House Speaker Tip O’Neill (Morrow 1984). Geraldine Ferraro, House Representative from New York's 9th district, became the first woman to run for vice presidency for a major party (Glass 2007). The Democratic staff hoped that her selection would change a campaign in which Mondale was trailing badly in the polls. And, in addition to attracting women, they hoped she could gain consensus among ethnic Democrats in the Northeast, that were a part of the electorate who had abandoned their party for Reagan in 1980 (Goldman and Fuller 1995, 228). Ferraro was also Roman Catholic and that, for the Democratic advisors, could have also helped with Catholic voters. As for the negative downsides, Ferraro did not have political experience at high level (Goldman and Fuller 1995, 237).

Among political experts, the choice of Ferraro was considered as a bet, and it was not sure if she could add votes or not to the Mondale campaign (Braden, 1996, 111). Although her selection was appreciated by the majority of the Democratic activists, opinion polls conducted right after the national convention showed that only 22 percent of women voters liked Ferraro's selection, versus 18 percent who thought she was not the best available candidate. Furthermore, 33 per cent of all voters believed that women's rights groups lobbying influenced Mondale's decision. Nonetheless, in the same days Ferraro proved to be able to run an energetic campaign and sometimes 
she was even able to obscure Mondale in the national media coverage. Mondale had been 16 points behind Reagan in polls before selecting Ferraro, and after the convention he even tied the race for a short time (Ferraro and Whitney 1998, 171-181).

On the Election Day, the Democratic ticket lost the race in a landslide. Reagan and Bush won the 59 per cent of the popular vote, while Mondale and Ferraro secured just 41 per cent of it. In the Electoral College, they carried only Mondale's home state of Minnesota and the District of Columbia. Ferraro was not even able to prevail in her own congressional district, which always tended to vote Republican in presidential races. Ferraro's contribution to the ticket - considered her supposed strength among minority voters - was poor. 55 per cent of women voters chose Reagan. And the incumbent President also got about the same percentage among Catholic voters, the highest level ever achieved by a Republican presidential candidate (Ferraro 2004, 312-313).

In 1976, Minnesota Senator Walter Mondale was on the other end of the ticket, when little-known Georgia's Governor, Jimmy Carter chose him, a liberal and political protégé of Hubert Humphrey, as his running mate. A selection which was probably made in order to add a "Northern" figure to balance the "Southern" Carter.

Eight years earlier, Spiro Agnew's moderate beliefs, immigrant ancestry, and popularity in a leaning Democratic state such as Maryland marked that he was the perfect match for the 1968 Republican presidential nominee, former Vice President Richard Nixon. As an example of what would later be defined Nixon's "Southern Strategy", Agnew was selected because he was enough from the South to fascinate the Southern moderate electorate, yet he did not represented the Deep South symbolically, which might have disheartened Northern centrist voters.

As the above, even "weird" strategies can stay behind the selection of the presidential running mate: in 1964, the vice presidential nomination went to little-known Republican Party Chairman William E. Miller, a New York Representative. Barry Goldwater, the Republican presidential candidate, stated that he chose Miller simply because "he drives [President] Johnson nuts" (Miller Fitzgerald 2004, 106).

In 1960, as mentioned at the beginning of this section, John F. Kennedy thought that he could not be elected without the back-up of traditional Southern Democrats, most of whom had supported Lyndon Johnson during the primaries. Kennedy asked Johnson to be the vice-presidential candidate the morning after being nominated for president (Caro 2012, 121-135). Robert F. Kennedy, who profoundly disliked Johnson for his previous harsh attacks against the Kennedy family, declared later that his brother made that offer to Johnson as an action of 
"political kindness" and did not expect him to accept the VP nomination. Investigative journalist Seymour Hersh $(1997,12)$ agrees with Robert Kennedy's reconstruction of the events, and wrote that John Kennedy would have preferred Missouri Senator Stuart Symington as his running-mate, but Johnson joined forces with House Speaker Sam Rayburn to influence Kennedy to favour himself. J

ohnson's biographer Robert Caro $(2012,132)$ offers different insights. He wrote that the Kennedy campaign was desperate to win what was predicted to be a very uncertain race. With Californian Richard Nixon and Massachusetts Senator Henry Cabot Lodge in the Republican ticket, Kennedy believed that Johnson was the right person to help carry Texas and the other Southern states. Despite his supposed brother's interference, John Kennedy met with political advisors such as Larry O'Brien, his national campaign manager, to share the decision that Johnson was to be Vice President. O'Brien confessed later that John Kennedy's words surprised him, but that after a brief thinking of the electoral vote situation, he realized that "it was a stroke of genius". When John and Robert Kennedy right after met with their father, Joe Kennedy, he told them that the Johnson's nomination was the best thing they had ever done (Caro 2012, 142).

General Eisenhower was the Republican presidential candidate in 1952 . He had no specific pre-agreements for a vice presidential candidate, and Republican national leaders suggested the name of Nixon. Eisenhower quickly agreed to the selection (Gellman 1999, 440-441). Nixon's young age (he was then only 39), his fierce attitude against communism, and his political stronghold in California - one of the largest battleground states at the time - were all considered as powerful credentials by the Republican establishment (Ambrose 1987, 342).

In 1952, after the nomination of Stevenson, the Democratic convention had to choose a vice president. The main candidates for this position were two Southern Senators: John Sparkman from Alabama and A. S. Mike Monroney from Oklahoma. President Truman and a restricted cabinet of political advisors chose conservative and segregationist Sparkman for the nomination. The convention complied with that and nominated Sparkman as Stevenson's running mate. Stevenson then famously stated that he aimed to commit himself to "talk sense to the American people." Again, Sparkman was chosen in order to balance the ticket.

The 1948 election is often accounted for being the greatest reversal in American presidential history. Almost every forecast pointed out that Harry Truman would be defeated by Thomas Dewey. Both parties suffered acute ideological ruptures, especially the Democratic Party that splitted apart, with the conservative wing and 
the far left running third-party campaigns. Truman nominated Kentucky Senator Alben W. Barkley, who had delivered the convention's keynote speech, as his running mate, with the selection proclaimed by acclamation (DiSalvo 2010). Civil rights bills, opposed by several Southern Democrats (such as Barkley), were crucial to Truman's Fair Deal (Libbey 1979, 93). But, because Barkley was popular among conservative Democrats, Truman asked him to be the vice presidential nominee (Libbey 1979, 94). And despite the perception that a ticket composed by a Missourian incumbent and a Kentuckian conservative lacked geographic balance, Truman and Barkley were able to win the election (Hatfield 1997, 4).

Four years earlier, although the party's conservatives could not prevent Franklin D. Roosevelt from running for a fourth term, the decline in the President's health brought many party national leaders to strongly oppose Henry Wallace, who was then Roosevelt's Vice President. He was considered by many Southern Democrats as being too liberal and somewhat personally outlandish. Even some progressives were suspicious about Wallace's New Age spiritual beliefs and for his relation with the controversial Nicholas Roerich, his personal Russian advisor. So, several party delegates decided to put in moderate Missouri Senator Harry Truman as FDR's fourth term VP nominee. Roosevelt, who was Wallace's friend and did not personally know Truman, unwillingly accepted Truman as his running mate in a bid not to break party cohesion. A few months later, the dispute around the vice presidential nomination suddenly became historic as Roosevelt died in April 1945 and therefore Truman assumed the Presidency instead of Wallace. It is also interesting to note that on the other side, in a similar effort to keep party unity, moderate presidential candidate Thomas Dewey chose conservative John William Bricker as his running mate.

Dewey was the Republican presidential nominee again in 1948 but Bricker was not the vice presidential candidate. Dewey decided to select California Governor Earl Warren, thinking that the 1948 ticket would win California which the Dewey-Bricker campaign had failed to do four years earlier. However, the Dewey-Warren ticket did not secure California and the absence of Bricker on the ticket may have been a factor in Dewey not winning Bricker's home state of Ohio again.

Wendell Willkie's nomination for the Republicans in 1940 is still considered by historians to have been one of the most dramatic moments in any political convention. Willkie did not care much about the name of his running mate and decided to leave the decision to convention chairman Joe Martin, who proposed Senate Minority Leader Charles L. McNary of Oregon. Wilkie reluctantly accepted the suggestion. Also because the two men did not agree on many things: "Whether as Vice President of the U.S. Charley McNary can keep on endorsing Government-power projects, isolation, 
high tariffs and huge outlays for farm relief under a President who believes in none of these things remains to be seen" (Neuberger 1940). Therefore, McNary seemed to be a Western farmer who has been selected in order to balance the figure of the presidential candidate Wendell Willkie, a pro-business Eastern politician (Neal 1985, 9). McNary's ideas appeared quite eccentric to Wilkie: the Oregon Senator supported the Progressive Era reforms and the direct election of the federal senators and he was an early campaigner for public rather than private power companies (Catledge 1940).

In 1932, once again, the "balancing strategy" was implemented by the Democratic presidential candidate, Governor of New York Franklin D. Roosevelt. He chose as his running mate John Nance Garner, who was a U.S. representative from Texas. Garner was a conservative Southern lawyer who contrasted the labour unions strikes of the '20s and later, when in office, he also harshly criticized the high public spending caused by the New Deal's policies.

Four years earlier, Republican Herbert Hoover, as many as other presidential candidates did, was not keen to interfere in the selection of his running mate. The decision was demanded to the party delegates who seemed to agree on confirming incumbent Vice President Dawes in the ticket. But as soon as the party's orientation started to spread, stepping down president Calvin Coolidge sent an angry telegram stating that he would consider a second nomination for Dawes, whom he hated, a "personal affront" (Mencken and Nathan 1929, 404). After that telegram, and with Coolidge still highly influential, it became virtually impossible for Dawes to pursue the VP nomination. Then the party decided to go for the usual strategy: in order to gain consensus among farmers concerned of Hoover's pro-business orientation, the nomination was destined to longtime Kansas Senator Charles Curtis (Mieczkowski and Carnes 2001, 94).

In the same year, the Democratic candidate was the Roman Catholic Governor of New York Al Smith. Worried that Smith spiritual beliefs would become an issue during the campaign (many Protestants were afraid that Smith would be influenced by the Pope instead of choosing the best for the country by his own), the Democratic establishment asked the delegates to select Senator Joseph Taylor Robinson of Arkansas as VP nominee. Robinson was Protestant and Southerner. He was also a dynamic politician and a gifted speaker. In some ways he was Smith's political nemesis (Binning et al. 1999, 135).

The 1924 Democratic primary season suffered a massive cultural and geographic shift in the party, as one wing (led by William Gibbs McAdoo) had its political base composed by rural, Protestant delegates from the South and the Midwest 
who were in favour of Prohibition. On the other hand, New York Governor Al Smith's was favoured by Catholics, ethnic minorities, anti-Prohibition supporters and delegates from the big-cities in the Northeast and urban Midwest. Because of the two-thirds rule, neither McAdoo nor Smith were able to win the nomination. Ballots followed other ballots and with this unprecedented situation, on the 100th count both Smith and McAdoo decided to abandon the race. Then the party convention was able to start looking for a compromise figure who would be acceptable to both McAdoo and Smith supporters (Prude 1972). Finally, on the 103rd ballot, the delegates chose John W. Davis as the presidential candidate. He was a former House Representative from West Virginia, virtually unknown to the press and to the greater audience. Nebraska Governor Charles Bryan, William Jennings Bryan's brother, was selected as VP nominee. The strategy behind this choice was to appeal to rural voters, whom still supported his brother, who was the leader of the populist wing and three times presidential candidate (Tucker 2010, 19).

\section{The Second Strategy: Carrying the Home State}

As the effects of the first strategy are mainly anecdotal and difficult to be measured, one thing we might be able to address, however, is whether a vice presidential nominee can help the candidate to carry his or her home state.

Although in 2012, Wisconsin, Paul Ryan's home state, was carried by Barack Obama; since 1920, major-party nominees for president have carried their VP's home state 64 percent of the time and the percentage is slightly higher than that, 71 percent in elections since World War II. This, however, is not statistically significant by itself. Instead, what we might try to investigate is to measure how many votes a vice presidential nominee bring to the ticket relative to how he would do otherwise.

The way to do this is to compare the presidential ticket's performance in the vice presidential nominee's state to his numbers nationwide. This analysis is taken (almost as it is) from Nate Silver's blog FiveThirtyEight (2012). As an example as the way it works, let's take a look at the 1948 elections: the Republican vice presidential nominee, California Governor Earl Warren, did not help Thomas Dewey to carry that state, which he lost to Harry Truman. The Dewey-Warren ticket came behind by 0.5 percentage points only in California, however, slightly better than the 4.5 percentage points it lost by nationwide. Silver call this difference the relative voting index, or RVI (Cook Political Report 2012). In the case above-mentioned, Warren had an RVI. of plus-4 for 1948, because his ticket did four points better in his home state than it did nationally. But, according to Silver, that still does not tell the whole story. Did Republicans' outperforming their 
national numbers by four percentage points in California have something to do with Governor Warren, or was it a red-leaning state at that time in general?

As compared to the previous election cycle of 1944, Warren's performance could be considered as very good, since Franklin D. Roosevelt did better in California that year than he performed nationally against Dewey's first presidential attempt. In fact, that year California had an RVI of negative-6. So, Warren might have provoked a net swing of 10.5 points, from an RVI of negative- 6 in 1944 to plus- 4 in 1948. On the other hand, in 1952, in California, Republicans had an RVI of plus14.5, despite Warren's no longer being on the ticket. But in that year and in the two subsequent elections, another candidate from California - Richard Nixon - was in one of the two tickets. So, the Warren effect can be calculated adding 1964 to the figure. In that year Lyndon Johnson won California by a margin of 18.3 points. Using 1948 as the baseline, in other words, averaging together the 1944 and 1964 comparisons, Warren's effect on the ticket in California is still positive (a net gain of almost five points of RVI) but not as astonishing as it originally seemed to be.

In Table 1 below, we have adjusted Silver's comparisons for all major-party vice presidential nominees since 1920. The comparison is between the ticket's RVI in the year the vice presidential candidate was on the ticket, the next and previous election cycles in which he was not on the ticket and when there was also no one else from his state running for President or Vice President.

For instance, in looking at the RVI for Sarah Palin, the Republican nominee for Vice President in 2008, the comparison years are 2004 (when Palin was not on the ticket, and nobody else from Alaska was) and 2012 (when Sarah Palin was not running and nobody else from Alaska was). In the last three elections, Republicans always carried Alaska. However, Palin did significantly better than Republican national numbers in 2008 (+28.8 points). Republicans low performed in 2004 (+23.1 R.V.I) and in 2012 $(+10.1$ R.V.I) and so the net gain in 2008 for Palin in her home state is +12.2 points.

There are also a few cases in which there were multiple candidates on the ticket from the same state in the same year. For instance, Henry Cabot Lodge Jr., Richard Nixon's vice presidential nominee in 1960, was from Massachusetts, the same state as the Democratic presidential nominee John F. Kennedy. Silver's model simply do not consider these years, since Lodge's performance might have been more a reflection of Kennedy's performance in Massachusetts than his own strengths and weaknesses.

Overall, the consensus advantage provided by a vice presidential nominee has been quite poor under this model. Since 1920, on average, it has given rise to a net gain 


\section{Morini}

\section{of about only 2.5 percentage points for the top of the ticket in his/her home state.}

Tab. 1: Vice presidential nominees since 1920. Net popular vote (gain).

\begin{tabular}{|c|c|c|c|c|c|c|c|c|c|c|}
\hline \multirow[b]{2}{*}{ Party } & \multirow[b]{2}{*}{ Candidate } & \multirow[b]{2}{*}{ State } & \multirow[b]{2}{*}{ EV } & \multirow[b]{2}{*}{ Year } & \multirow[b]{2}{*}{ RVI } & \multicolumn{2}{|c|}{ Previous Comparison } & \multicolumn{2}{|c|}{ Next Comparison } & \multirow[b]{2}{*}{$\begin{array}{l}\text { Net } \\
\text { Gain }\end{array}$} \\
\hline & & & & & & Year & RVI & Year & RVI & \\
\hline $\mathrm{D}$ & Biden & $\mathrm{DE}$ & 3 & 2012 & $+14,7$ & 2004 & $+10,1$ & & & $+4,6$ \\
\hline $\mathrm{R}$ & Ryan & WI & 3 & 2012 & -3 & 2008 & $-6,7$ & & & $+3,7$ \\
\hline $\mathrm{D}$ & Biden & $\mathrm{DE}$ & 3 & 2008 & $+17,7$ & 2004 & $+10,1$ & & & $+7,7$ \\
\hline $\mathrm{R}$ & Palin & AK & 3 & 2008 & $+28,8$ & 2004 & $+23,1$ & 2012 & $+10,1$ & $+12,2$ \\
\hline $\mathrm{D}$ & Edwards & $\mathrm{NC}$ & 15 & 2004 & -10 & 2000 & $-13,4$ & 2008 & $-6,9$ & $+0,2$ \\
\hline $\mathrm{R}$ & Cheney & WY & 3 & 2004 & $+37,3$ & 2000 & $+21,5$ & 2008 & $+39,5$ & $+6,8$ \\
\hline $\mathrm{D}$ & $\begin{array}{l}\text { Lieber- } \\
\text { man }\end{array}$ & CT & 8 & 2000 & +17 & 1996 & $+9,6$ & 2004 & $+12,5$ & $+5,9$ \\
\hline $\mathrm{R}$ & Cheney & WY & 3 & 2000 & $+40,6$ & 1996 & $+21,5$ & 2008 & $+39,5$ & $+10,1$ \\
\hline $\mathrm{D}$ & Gore & TN & 11 & 1996 & $-6,1$ & 1988 & $-8,6$ & 2004 & $-11,8$ & $+4,1$ \\
\hline $\mathrm{R}$ & Kemp & NY & 33 & 1996 & $-20,3$ & 1992 & $-10,3$ & 2000 & $-24,5$ & $-2,9$ \\
\hline $\mathrm{D}$ & Gore & $\mathrm{TN}$ & 11 & 1992 & $-0,9$ & 1988 & $-8,6$ & 2004 & $-11,8$ & $+9,3$ \\
\hline $\mathrm{R}$ & Quayle & IN & 12 & 1992 & $+11,8$ & 1984 & $+5,5$ & 1996 & $+14,1$ & +2 \\
\hline $\mathrm{R}$ & Quayle & IN & 12 & 1988 & $+12,4$ & 1984 & $+5,5$ & 1996 & $+14,1$ & $+2,6$ \\
\hline $\mathrm{D}$ & Ferraro & NY & 36 & 1984 & $+10,2$ & 1980 & $+7,1$ & 1988 & $+11,8$ & $+0,8$ \\
\hline $\mathrm{R}$ & Bush & TX & 29 & 1984 & +9 & 1976 & $+1,1$ & 1996 & $+13,5$ & $+1,7$ \\
\hline $\mathrm{D}$ & Mondale & $\mathrm{MN}$ & 10 & 1980 & $+13,7$ & 1972 & $+17,6$ & 1988 & $+14,8$ & $-2,5$ \\
\hline $\mathrm{R}$ & Bush & $\mathrm{TX}$ & 26 & 1980 & $+4,1$ & 1976 & $+1,1$ & 1996 & $+13,5$ & $-3,2$ \\
\hline $\mathrm{D}$ & Mondale & $\mathrm{MN}$ & 10 & 1976 & $+10,8$ & 1972 & $+17,6$ & 1988 & $+14,8$ & $-5,4$ \\
\hline $\mathrm{R}$ & Dole & KS & 7 & 1976 & $+9,6$ & 1972 & +15 & 1980 & $+14,8$ & $-5,3$ \\
\hline $\mathrm{D}$ & Muskie & $\mathrm{ME}$ & 4 & 1968 & $+11,5$ & 1964 & $+15,1$ & 1972 & $+0,5$ & $+3,7$ \\
\hline $\mathrm{R}$ & Agnew & $\mathrm{MD}$ & 10 & 1968 & $-2,3$ & 1964 & $-8,4$ & 1976 & -4 & $+3,9$ \\
\hline $\mathrm{D}$ & $\begin{array}{l}\text { Hum- } \\
\text { phrey }\end{array}$ & $\mathrm{MN}$ & 10 & 1964 & $+5,2$ & 1960 & $+1,3$ & 1972 & $+17,6$ & $-4,3$ \\
\hline $\mathrm{R}$ & Miller & NY & 43 & 1964 & $-14,7$ & 1960 & $-5,1$ & 1968 & $-6,2$ & -9 \\
\hline $\mathrm{D}$ & Johnson & $\mathrm{TX}$ & 24 & 1960 & $+1,8$ & 1956 & $+4,1$ & 1968 & +2 & $-1,2$ \\
\hline $\mathrm{D}$ & Kefauver & $\mathrm{TN}$ & 11 & 1956 & $+14,8$ & 1952 & $+10,6$ & 1960 & $-7,3$ & $+13,2$ \\
\hline $\mathrm{R}$ & Nixon & CA & 32 & 1956 & $-4,3$ & 1944 & -6 & 1964 & $+4,3$ & $-3,4$ \\
\hline $\mathrm{D}$ & Sparkman & $\mathrm{AL}$ & 11 & 1952 & $+40,4$ & 1944 & $+56,6$ & 1956 & $+32,4$ & $-4,1$ \\
\hline $\mathrm{R}$ & Nixon & $\mathrm{CA}$ & 32 & 1952 & $+3,7$ & 1944 & -6 & 1964 & $+4,3$ & $+4,6$ \\
\hline $\mathrm{D}$ & Barkley & $\mathrm{KY}$ & 11 & 1948 & $+10,8$ & 1944 & $+13,7$ & 1952 & $+10,9$ & $-1,6$ \\
\hline $\mathrm{R}$ & Warren & $\mathrm{CA}$ & 25 & 1948 & +4 & 1944 & -6 & 1964 & $+4,3$ & $+4,9$ \\
\hline $\mathrm{D}$ & Truman & MO & 15 & 1944 & $-4,6$ & 1940 & $-4,8$ & 1952 & $+9,3$ & $-6,8$ \\
\hline $\mathrm{R}$ & Bricker & $\mathrm{OH}$ & 25 & 1944 & $+7,1$ & 1940 & $+5,5$ & 1948 & $+4,2$ & $+2,2$ \\
\hline $\mathrm{D}$ & Wallace & IA & 11 & 1940 & $-14,4$ & 1936 & $-12,5$ & 1944 & -12 & $-2,1$ \\
\hline $\mathrm{R}$ & McNary & OR & 5 & 1940 & $+1,9$ & 1936 & $-10,5$ & 1944 & $+2,6$ & $+5,8$ \\
\hline
\end{tabular}




\begin{tabular}{|l|l|l|l|l|l|l|l|l|l|l|}
\hline D & Garner & TX & 23 & 1936 & $+50,5$ & 1928 & $+13,8$ & 1940 & +62 & $+12,6$ \\
\hline R & Knox & IL & 29 & 1936 & $+6,2$ & 1932 & $+4,6$ & 1940 & $+6,9$ & $+0,5$ \\
\hline D & Garner & TX & 23 & 1932 & +59 & 1928 & $+13,8$ & 1940 & +62 & $+21,1$ \\
\hline R & Curtis & KS & 9 & 1932 & $+8,3$ & 1924 & $+12,7$ & 1940 & $+24,4$ & $-10,2$ \\
\hline D & Robinson & AR & 9 & 1928 & $+38,4$ & 1924 & $+57,2$ & 1932 & $+55,3$ & $-17,8$ \\
\hline R & Curtis & KS & 10 & 1928 & $+27,5$ & 1924 & $+12,7$ & 1940 & $+24,4$ & +9 \\
\hline D & Bryan & NE & 8 & 1924 & $+7,7$ & 1920 & $-7,2$ & 1928 & $-9,6$ & $+16,1$ \\
\hline R & Dawes & IL & 29 & 1924 & $+10,3$ & 1920 & $+16,1$ & 1928 & $-2,8$ & $+3,6$ \\
\hline D & Roosevelt & NY & 45 & 1920 & $-11,4$ & 1916 & $-10,1$ & 1924 & $-1,4$ & $-5,7$ \\
\hline R & Coolidge & MA & 18 & 1920 & $+14,5$ & 1916 & $+7,1$ & 1928 & $-18,5$ & $+20,3$ \\
\hline Average & & & & & $+10,66$ & & $+6,52$ & & $+10,33$ & $+2,44$ \\
\hline
\end{tabular}

Table 1 shows an impressive series of inferences. But there are also several questionable points connected to this analysis. First of all, and using the words of the author of the chart, the model takes for granted that the vice presidential nominee is popular in his/her home state. That is certainly sure for recent candidates such as Ryan, Biden, Palin, Cheney and so on. But it is difficult to check it out for candidates from the distant past. Indeed, it might have happened that some of the nominees were not much appreciated by their fellow citizens. And, of course, there is no reason to expect vice presidential candidates to give rise to a home-state effect if the approval rating polls point out that the voters in his/her state don't like them.

A second observation is that the net advantage determined by the vice presidential candidates has been greater in recent years - more than four points on average rather than two in elections since 1984. That could just be a statistical coincidence, although it could also show the fact that vice presidential nominees are having a greater impact than they once did. Lately, only a few VP nominee were not able to win their own state. However, on a different point of view, almost all the VP nominee coming from battleground states or states that were difficult to win for their party lost their own territory: Paul Ryan in Wisconsin in 2012, John Edwards in North Carolina in 2004, Jack Kemp in New York in 1996, Lloyd Bentsen in Texas in 1988 (although the Republican presidential candidate George $\mathrm{H}$. W. Bush was coming from Texas as well) and Geraldine Ferraro in New York in 1984. The only significant exception is represented by Al Gore, who, as a Democratic vice presidential candidate in 1992 and in 1996 was able to win in his own Tennessee, a state that had not voted Republican for the previous sixteen years. Paradoxically, four years later, when he was the Democratic presidential candidate, Al Gore lost Tennessee to George W. Bush (Romero 2001).

Third, data suggest that some vice presidential nominees produce more impact than others. Current governors or senators have given rise to a quite larger gain on average 
(about 4 points rather than 1.5) than those who were no longer in office, or who were U.S. representatives and therefore represented a single House district rather than the whole state. And thisis also easilyintuitive: senators and governors also serve for longer terms and they usually benefit from more extensive media coverage (Cohen 2001).

Fourth, the effects are probably more sounding in smaller states than in bigger ones, maybe because their political cultures are more cohesive and it's rarer for them to see a native son nominated to a presidential ticket. Vice presidential nominees from states with fewer electoral votes have historically provided a larger home-state boost - Joe Biden and Sarah Palin each had significant effects in Delaware and Alaska in 2008.

Fifth, although electoral coalitions have been quite steady in the recent decades, that has not always been like this; Vermont was once one of the most Republican states in the country, and Arizona one of the most Democratic. Therefore, it seems that there are many controversial messages in the data, as these alterations can sometimes be more powerful than any effect a vice presidential nominee might have.

A different method of analysis might be able to cover some of these issues, although other problems are probably not tractable given the relative scarcity of data (just one presidential election every four years) and the inherent challenge in searching the causes behind anyone's vote. With that said, it seems that the vice presidential nominee's effect on his or her home state is normally pretty modest, just around two or three percentage points on average. Certainly, two or three percentage points in one or more swing states is something that every candidate would hope to achieve, but it is probably not enough to overstate the other variables - positive and negative - that a vice presidential candidate could potentially bring in to the ticket.

Indeed, in the last two decades, presidential campaigns have not resorted in this principle, with recent vice presidential nominees coming from states like Alaska, Connecticut, Delaware and Wyoming that are currently considered not competitive. In 2012, however, Mitt Romney decided to "risk" again, picking Paul Ryan from Wisconsin, a potential battleground state. Although Ryan halved the gap between Republicans and Democrats, he was not able to turn his home state to Red (it would have been the first time since 1984).

\section{Conclusion}

In the first section of this paper we aimed to list and briefly describe the most meaningful vice presidential choices since 1920. Obviously, at a first sight, the main reason for selecting the running mate has been to make the tick- 
et more appealing for voters. On a more exhaustive analysis, however, the more common rationale appears the one that aims to "balance the ticket".

The VP candidate is often chosen to complement the top of the ticket geographically (a presidential candidate from the North should run together with a VP from the South: Kennedy-Johnson in 1960, for example). Or politically, in order to keep all the "wings" of the party together: a perfect example comes from the 1948 elections when Thomas Dewey, a moderate Republican, chose the conservative John William Bricker as his running mate. Also other dichotomies are quite common: youth v. seniority - or in the other sense: experience v. inexperience - and in this group can be placed the tickets Bush sr.-Quayle, McCain-Palin and also Obama-Biden.

These are the most evident rationales but probably also other explanations staybehind each vice presidential selection. And it is also possible that some of them are probably just the outcome of an over interpretation of the events. What it appears clear is that presidential candidates want to offer to voters the most extensive ticket possible. The VP should add to the presidential candidate the qualities, the characteristics and the votes that the presidential nominee doesn't have or that he is not able to carry himself.

Millions of lines have been written about VP candidates' selection, campaign performances and also about their possible political outcomes on the final electoral result. But it is never been easy to measure the real VP effect. The scientific literature is not extensive and it usually focuses at national level. Collecting opinion polls and correlating different voting data is the usual method to estimate the VP nominee effect in the presidential elections. The analysis proposed in the second paragraph is less ambitious but perhaps more accurate.

Based on the model elaborated by statistician Nate Silver, the idea was to measure the VP nominee effect in his/her home state. Basically, the model aimed to estimate the so-called native son effect, that is, usually, the second reason for selecting one running mate instead of another. Or, at least, it is something expected from the vice presidential candidate. Additionally, for what concerns "integrating geographically the Presidential candidate's characteristics", this strategy can also be considered inter-related to "carrying the home state". Think about the selection of Johnson in 1960 and Edwards in 2004: we know they were chosen because they came from the South, so their potential home-state effect could have been spread around their neighbouring states.

Paradoxically, this analysis may be complicated by the inter-relation with the factor explained in the first section, that is the potential for ticket-balancing. For example, John Kerry may have picked John Edwards of North Caro- 
lina in 2004 because he was worried about how he might perform in the South. If a presidential candidate is deliberately selecting a vice presidential nominee from a state where he otherwise expects not to gain many votes, an analysis like this might inaccurately allocate a poor performance to the vice presidential candidate when the problem is with the top of the ticket instead.

The most interesting outcome from section two is that the vice presidential effect in his/her home state is poor. At first glance, it could appear huge - because each presidential campaign is usually compared only with the previous and the next. But, when the interference with other candidates is removed, and though each home state effect is correctly compared with the right election, numbers lower significantly. The 2.5 per cent average net gain showed in Table 1 looks even almost irrelevant if we consider the whole political landscape, namely the Electoral College system. Indeed, the biggest gains are from VP nominees who came from states that were not up for grab, but solidly voting for their party. So, what's the point for Republicans - for instance - of winning Alaska by 20 points instead of 10 ? Or for Democrats to secure Delaware by a margin of 18 points instead of 10 ? In terms of winning the presidency, there is no sense. Many of the last VP nominees came from "safe" states, where their victory was already sure since the beginning. The few latest exceptions were Al Gore in 1992 and 1996, Jack Kemp in 1996, John Edwards in 2004 and Paul Ryan in 2012. Except for Gore, all lost their home state. And Kemp and Edwards even had a counter-productive effect, because they got a negative balance compared to their party's previous performance in those states. Going back a little, it is worthwhile to mention the Walter Mondale 1976's success in Minnesota, a state that four years earlier voted for Nixon (but that voted for Humphrey, Johnson and Kennedy previously). There are also other cases in the further past, but they all happened before the last political realignment (the one of the late -60 's-early -70's) and so it is not that easy to make diachronic comparisons.

It is difficult to draw general rules from this analysis. What it is sure is that many of the recent VP candidates came from non-competitive states and that the VP nominees' effect in their home state is paltry. In general, it seems more common the idea that the VP candidate is chosen with the attempt to balance the ticket. It is a strategy that concerns the party's inner balance and its necessity not to alienate some portions of the electorate. In these cases, the most employed tactic is to select moderate VP for radical presidential candidates (or vice versa), Southern VP for Northern candidate (or vice versa) or young VP for expert candidates (or vice versa). We have also seen how sometimes - especially in the past - the VP process of selection is left to the party's establishment or it is considered a minor issue. 
On this point, we should bear in mind what statistics suggest: despite the low effective powers granted by Article II of the Constitution, Vice Presidents usually have a bright future in front of them. Since 1900, about 25 percent of the people nominated for Vice President by Republicans and Democrats have later become presidential nominees themselves, and 15 percent have actually become president, whether by winning the office on their own or by succeeding an incumbent who died or resigned in office.

\section{References}

Adkinson, Daniel. 1982. "The Electoral Significance of the Vice Presidency," Presidential Studies Quarterly 12 (Summer 1982): 330-36.

Ambrose, Stephen E. 1987. Nixon: The Education of a Politician 1913-1962. New York: Simon \& Schuster.

Binning, William C., William C. Larry, Eugene Esterly and Paul A. Sracic. 1999. Encyclopedia of American Parties, Campaigns, and Elections. Westport, Conn.: Greenwood Press, 1999.

Braden, Maria. 1996. Women Politicians and the Media. Lexington: The University Press of Kentucky.

Caro, Robert A. 2012. The Passage of Power. New York: Alfred A. Knopf.

Catledge, Turner. 1940. "Senator Drafted: New Party Rulers Pick Veteran Farm Leader to Balance Ticket," The New York Times, 29 June.

Cohen, Jeffrey E. 2001. "Popular Views of the Vice President: Vice Presidential Approval." Presidential Studies Quarterly 31: 142-49.

Cook Political Report. 2012. The Relative Vote Index, 28 May, URL:

http://cookpolitical.com/user/login?destination=/presidential/charts (retrieved 11 May 2013).

Devine, Christopher, and Kyle Kopko. 2011. "The Vice Presidential Home State Advantage Reconsidered: Analyzing the Interactive Effect of Home State Population and Political Experience, 18842008," Presidential Studies Quarterly 41 (1): 1-17.

Devine, Christopher, and Kyle Kopko. 2013. "Presidential Versus Vice Presidential Home State Advantage: A Comparative Analysis of Electoral Significance, Causes, and Processes, 1884- 2008," Presidential Studies Quarterly 43: 814-838.

DiSalvo, Daniel. 2010. "The Politics of a Party Faction: The Liberal-Labor Alliance in the Democratic Party, 1948-1972," Journal of Policy History 22: 269-299.

Ferraro, Geraldine and Catherine Whitney. 1998. Framing a Life: A Family Memoir. New York: Scribner.

Ferraro, Geraldine. 2004. My Story. Evanston: Northwestern University Press.

Gellman, Irwin. 1999. The Contender. New York: The Free Press.

Glass, Andrew. 2007. "Ferraro joins Democratic ticket July 12, 1984", The Politico, 12 July.

Goldman, Peter and Tony Fuller. 1995. The Quest for the Presidency 1984. New York: Bantam Books.

Goldstein, Joel. 2007. "Presidential Ticket-balancing." In The American Midwest: An Interpretive Encyclopedia, eds. Richard Sisson, Christian Zacher and Andrew Clayton. Indianapolis: Indiana University Press.

Grofman Bernard, and Reuben Kline. 2010. "Evaluating the Impact of Vice Presidential Selection on Voter Choice," Presidential Studies Quarterly 40(2): 303-309.

Gruhl, John, Sue Thomas, Susan M. Rigdon and Susan Welch. 2012. Understanding American Government. Wadsworth: Cengage Learning. 
Hatfield, Mark O. 1997. “Alben W. Barkley (1949-1953)”. In Vice Presidents of the United States, 1789-1993. Washington, D.C.: U.S. Government Printing Office.

Hersh, Seymour M. 1997. The Dark Side of Camelot. Boston: Little, Brown \& Company.

Knuckey, Jonathan. 2012. “The "Palin Effect” in the 2008 U.S. Presidential Election," Political Research Quarterly 65 (2): 275-289.

Libbey, James K. 1979. Dear Alben: Mr. Barkley of Kentucky. Lexington, Kentucky: The University Press of Kentucky.

Mencken, Henry L. and George J. Nathan. 1929. The American Mercury. New York: Alfred A. Knopf.

Mieczkowski, Yanek and Mark Christopher Carnes. 2001. The Routledge Historical Atlas of Presidential Elections. New York: Routledge.

Miller Fitzgerald, Libby. 2004. Bill Miller-Do You Know Me?: A Daughter Remembers. Lynchburg, VA: Warwick House Publishers.

Morrow, Lance. 1984. "Why Not a Woman?" Time, 4 June.

Neal, Steve. 1985. McNary of Oregon: A Political Biography. Portland, OR: Western Imprints.

Neuberger, Richard. 1940. "M'Nary Is Strong in the Northwest," The New York Times, 7 July.

Prude, James. 1972. "William Gibbs McAdoo and the Democratic National Convention of 1924".

The Journal of Southern History (Southern Historical Association) 38 (4): 621-628.

Romero, David W. 2001. "Requiem for a Lightweight: Vice Presidential Candidate Evaluations and the Presidential Vote.” Presidential Studies Quarterly 31: 454-63.

Silver, Nate. 2012. "The Overrated Vice Presidential Home-State Effect” The New York Times, 23 April. URL: http://fivethirtyeight.blogs.nytimes.com/2012/04/23/the-overrated-vice-presidential-home-state-effect/ (retrieved 18 August 2013).

Tucker, Garland S. III. 2010. The High Tide of American Conservatism: Davis, Coolidge and the 1924 Election. New York: Emerald.

Ulbig, Stacy. 2010. “The Appeal of Second Bananas: The Impact of Vice Presidential Candidates on Presidential Vote Choice, Yesterday and Today," American Politics Research 38 (2): 330-355.

Wattenberg, Martin P. 1995. "The Role of Vice Presidential Candidate Ratings in Presidential Voting Behavior," American Politics Research 23 (October 1995): 504-14.

Wattenberg, Martin P., and Bernard Grofman. 1993. "A Rational Choice Model of the President and Vice-President as a Package Deal.” In Information, Participation, and Choice: An Economic Theory of Democracy in Perspective, ed. Bernard Grofman. Ann Arbor: University of Michigan Press: 173-77. 